\title{
Medial Rectii Recessions a Surgical Procedure for Bil Alternating Infantile Esptropia in 6 Months Male Twins
}

\author{
Gowhar Ahmad* \\ Department of ophthalmology, University of Jammu and Kashmir, India
}

Submission: April 04, 2017; Published: June 06, 2017

*Corresponding author: Gowhar Ahmad, Department of ophthalmology, University of Jammu and Kashmir, India, Tel: 9419009850/ 9622983444: Email: gowhar.ahmad1948@gmail.com

\section{Abstract}

6 months un identical twins were seen by me in 2002 at qatif central hospital eastern province ks a with parents having noticed bill alternating inward ocular deviation since 2 monthsft normally delivered twins no history of exposure to oxygen birth trauma convulsions jaundice fever or any other cong ocular disorder like 1 sclera cornea 2 keratitis corneal dystophy peters corneal anomaly or limbal corneal dermoid on exam both twins dhad bil alt 15 degrees esotropia no limitation of ocular movements 2 no turning of head towards the direction of paralysed muscle 3 no diplopia 4 no abnormal head posture or false orientation under sedation mydriatic refraction and fundus examination was done ref was equal in both eyes in both eyes so were the normal fundii key words esotropia is inward ocular deviation 2 expotropia is outward ocular deviatin 3 hetrophoria is latenr ocular deviatin 4 infantile is age from birth to 3 years .

\section{Introduction}

squint is a common ocular disorder nowadays due to abuse of playing games on mobiles and i pads incidence of ocular deviation has increased recently I saw twins of 6 years of age parents complained that one twin had left eye ocular deviation since 3 months as this twin was constantly playing video games on exam this twin had plus $2 \mathrm{~d}$ cylinder 130 axis other twin as he was not playing games was normal squints can be 1 esotopia 2 esotropia 3 heterotopias 4 paralytic 5 non paralytic 6 accommodative 7 non accommodative 8 pseudo squint in those who have broad bridge of nose epicanthal folds and wide inter canthal distance results of bill alt infantile esotropia with bill $5 \mathrm{~mm}$ medial rectii recessions are very satisfactory both 1 from correction of angle of squint and reaction of eye which is minimal [1].

\section{Discussion}

Bill alt esotropia presents as 1 crossed fixation 2 uncrossed fixation 3 over action of inf oblique 4 a v patern 5 broad angle 6 covering the dominant eye will make p child to cry so after all investigations under $\mathrm{g}$ a both twins were operated under $\mathrm{g}$ a exposure of eye done with eye speculmm rotation of eye ensyred with 6 zero silk sutures $5 \mathrm{~mm}$ recessions of medial rectii one and position of muscle secured on sclera using 6 zero vicoryl suture closure of conjuctival wound done with 8 zero silk sures next day children had very satisfactory correction of angle of deviation and most important thing was that eye reaction was minimal

\section{Conclusion}

Bill $\mathrm{m}$ rectii recessions is a very satisfactory procedure for cases of bill alt infantile esotropia as we do not cut muscle that is resection so the eye reaction is minimal and secondly correction of eye deviation is good I did this procedure in 2002 even today same procedures is done even after 17 years due to satisfactory modality of this surgical procedure however some complications $r$ seen like 1 under correction 2 over action of inf oblique 3 amblyopia $4 \mathrm{~d} v \mathrm{~d}$ dissociated vertical deviation 5 accommodative element in my cases more than 1 buyers follow up of twins was normal.

\section{References}

1. Habot-Wilner Z, Spierer A, Glovinsky J, Wygnanski-Jaffe T (2006) Bilateral medial rectus muscle recession: results in children with developmental delay compared with normally developed children. J AAPOS 10(2): 150-154. 

(C) Commons Attribution 4.0 License BY DOI:10.19080/JOJ0.2017.03.555610
Your next submission with Juniper Publishers will reach you the below assets

- Quality Editorial service

- Swift Peer Review

- Reprints availability

- E-prints Service

- Manuscript Podcast for convenient understanding

- Global attainment for your research

- Manuscript accessibility in different formats

( Pdf, E-pub, Full Text, Audio)

- Unceasing customer service

Track the below URL for one-step submission https://juniperpublishers.com/online-submission.php 